RACAR : Revue d'art canadienne

Canadian Art Review

\title{
Francesco Trevisani's Design for the Frontispiece to the Theses iuris publicae disputationi of Antonio Zondadari (1689)
}

\section{Roya Abouzia}

Volume 15, numéro 2, 1988

URI : https://id.erudit.org/iderudit/1073375ar

DOI : https://doi.org/10.7202/1073375ar

Aller au sommaire du numéro

\section{Éditeur(s)}

UAAC-AAUC (University Art Association of Canada | Association d'art des universités du Canada)

\section{ISSN}

0315-9906 (imprimé)

1918-4778 (numérique)

Découvrir la revue

\section{Citer cette note}

Abouzia, R. (1988). Francesco Trevisani's Design for the Frontispiece to the Theses iuris publicae disputationi of Antonio Zondadari (1689). RACAR: Revue d'art canadienne / Canadian Art Review, 15(2), 148-149.

https://doi.org/10.7202/1073375ar
Résumé de l'article

La gravure qui sert de frontispice à un livre de science juridique dédié au cardinal Flavio Chigi II présente un certain nombre de références symboliques à cet important personnage. Les éléments architecturaux évoquent le Temple de la Sagesse et les portraits dans les médaillons mettent en évidence les liens qui unissent Chigi à la papauté et aux traditions intellectuelles de son ancêtre le plus prestigieux.
Tous droits réservés @ UAAC-AAUC (University Art Association of Canada | Association d'art des universités du Canada), 1988
Ce document est protégé par la loi sur le droit d'auteur. L'utilisation des services d'Érudit (y compris la reproduction) est assujettie à sa politique d'utilisation que vous pouvez consulter en ligne.

https://apropos.erudit.org/fr/usagers/politique-dutilisation/ 


\section{Francesco Trevisani's Design for the Frontispiece to the Theses iuris publicae disputationi of Antonio Zondadari (1689)}

ROYA ABOUZIA

Montreal, Quebec

\section{RÉSUMÉ}

La gravure qui sert de frontispice à un livre de science juridique dédié au cardinal Flavio Chigi i présente un certain nombre de références symboliques à cet important personnage. Les éléments architecturaux évoquent le Temple de la Sagesse et les portraits dans les médaillons mettent en évidence les liens qui unissent Chigi à la papauté et aux traditions intellectuelles de son ancêtre le plus prestigieux.
The Print Collection of the Department of Rare Books and Special Collections of McGill University in Montreal owns an engraving dedicated to Cardinal Flavio Chigi in (European folio 839). Designed by Francesco Trevisani, it was prepared for publication in 1689 by Arnold van Westerhout (Fig. 104). Given what it says about the art patronage of Cardinal Chigi II, the frontispiece, previously mentioned only in Bodart's Catalogue Raisonné, ' deserves to be better known.

The designer of the print, Francesco Trevisani, was born at Capo d'Istria in 1656 and died in Rome in 1746 . Known mainly for his history paintings, Trevisani received his artistic education in Venice under Antonio Zanchi and in Rome under Carlo Maratti. Favoured by the patronage of Cardinal Chigi II, Trevisani received from him an entry into the circle of Pope Clement XI. ${ }^{2}$ The engraver, Arnold van Westerhout, was born in

1 The only mention of this print is in Didier Bodart, L'oeuvre du graveur Arnold van Westerhout (1651-1725). Essai de catalogue raisonné (Brussels, 1976), xiv, 9-12.

2 Frank R. DiFederico, Francesco Trevisani: Eighteenth-Century Painter in Rome. A Catalogue Raisonné (Washington, D.C., 1977); E. Benezit, Dictionnaire critique et documentaire des Peintres, Sculpteurs, Dessinateurs et Graveurs (Saint-Ouen, 1966), vill, 377; Bryan's Dictionary of Painters and Engravers (London, 1921), v, 204.
Antwerp in 1651. From 1681 to 1686 , van Westerhout was in Rome. Between 1687 and 1692, he travelled extensively throughout Italy, spending no fewer than three years in Florence where he served as court painter to Grand Duke Ferdinand. Van Westerhout died in Rome on 18 April $1725 .^{3}$

Cardinal Chigi in, to whom the Theses frontispiece is dedicated, is portrayed in the upper lefthand corner of the engraving in a roundel carried by two angels. The frontispiece was commissioned by Cardinal Chigi in for his nephew Antonio Zondadari (1669-1744). ${ }^{4}$ The figure of Wisdom is shown enthroned in the centre of the composition, her companions being Religion and Prudence (left) and Peace (right). Aided by a putto, Peace presents to Wisdom an architectural drawing. This drawing presumably relates to the columns strewn across the foreground since there are seven both in the drawing and on the ground. A clue as

3 From 1716 to 1725 , he was engraver to François-Marie, Duke of Parma.

4 Vincenzo Golzio, Documenti artistici sul seicento nell'Archivio Chigi (Rome, 1939), 256-57. About a century earlier, this particular manner of presentation was already seen in the North, for instance in the frontispiece designs by PeterPaul Rubens. See illustrations in J. Richard Judson and Carl van de Velde, Corpus Rubenianum Ludwig Burchard, Book Illustrations and Title-Pages (Brussels, 1978), u. 
to the identification of the building under construction is provided by the text of the banner held by Fame, whose trumpet bears Cardinal Chigi In's coat of arms: "Sapientia aedificavit sibi donum excidit columnas septem." Taken from Proverbs 9, the inscription reads in translation: "Wisdom hath built her house, she hath hewn out her seven pillars." Surely it is no accident that both the drawing and the foreground have the same number of columns mentioned in the inscription. Accordingly, Peace is shown presenting to Wisdom the plan for the Temple of Wisdom, the columns of which are shown in the foreground in various states of completion.

The principal figures in the Westerhout engraving are depictions of Cardinal Chigi II's virtues. They are identified by the attributes they hold, attributions related to Cesare Ripa's Iconologia ${ }^{5}$, a publication widely used during the seventeenth century by artists and theological advisors. According to St. Thomas, Religion is a moral virtue by which humanity as a whole venerates and honours God spiritually and physically through prayer and participation in rites. ${ }^{6}$ Prudence, with the serpent and mirror, acts upon events so as to bring one to one's own felicity in life by following the good and avoiding evil. ${ }^{7}$ Wisdom holds the eternal secrets of God and it is only through our faults that our understanding loses its clarity - it is darkened by the vices that diminish the production of knowledge. ${ }^{8}$ Finally, Peace holds a cornucopia representing abundance and is the constant object of all peoples' striving. ${ }^{9}$ Thus, Cardi-

5 Cesare Ripa, Iconologie, translated by Jean Baudouin (New York and London, 1976), Cesare Ripa's Iconologia was first published in 1593 in Rome without illustrations. The first illustrated edition was published in Rome in 1603. The association of allegorical figures with personages as a method of characterization was used by previous, contemporary, and later artists.

6 Ripa, Iconologie, 170-71, plate cxull

7 Ripa, Iconologie, 164, plate cxxxviI.

8 Ripa, Iconologie, 174-75, plate cxLVIII.

9 Ripa, Iconologie, 138-40, plate cxv. nal Chigi in is represented as a true Christian with fervent faith who is prudent as well as being a wise man striving for peace.

The putti who sit among the columns in the foreground are mainly occupied in holding roundel portraits whose features they are shown to be sculpting. Bodart considers them to be representatives of the liberal arts, ${ }^{10}$ but their only attributes (hammer and chisel and compass) are, at best, symbols of logic, arithmetic, and geometry. Four of the portraits are readily identifiable: Paul v, Gregory xv, Urban viII, and Innocent x. The remaining two, those carried aloft by putti, are as yet unidentifiable cardinals.

It is not known precisely why Cardinal Chigi II paid for Zondadari's publication. It is easier to understand why the frontispiece to the Theses glorifies the cardinal who was a distinguished patron of the arts. ${ }^{11}$ One feature of the engraving remains to be discussed: the decoration of the fluted columns. Not all of the motifs are easily read but the crowned eagle may refer to the cardinal's involvement in political and diplomatic matters, while the dove holding an olive branch defines the cardinal as a man of peace. As for the bee, it is an emblem of activity, diligence, and eloquence. ${ }^{12}$ If one single meaning can be assigned to the frontispiece to the Theses, it is its function as a commemorative emblem of the life and patronage of Cardinal Chigi II.

10 Bodart, Catalogue Raisonné, 47.

11 Dizionario Biografico degli Italiani (Rome, 1980), xxıv, 750-51. In the minor arts, he commissioned mosaicists, miniaturists, engravers, and medallists.

12 Ad. de Vries, Dictionary of Symbols and Imagery (A msterdam, 1974); J. E. Cirlot, A Dictionary of Symbols, translated by Jack Sage (New York, 1962); Eug. Droulers, Dictionnaire des Attributs, Allegories Emblemes et Symboles (Turnhout, n.d.). The bees are probably not those of the Barberini because the bees are set apart from each other and are not in the traditional triangular flight formation of the Barberini emblem, and because there is no consistency in the application of the ornamentation to the coat-of-arms of the popes

4461 Beaubien East Montreal, Quebec H1T1T3 


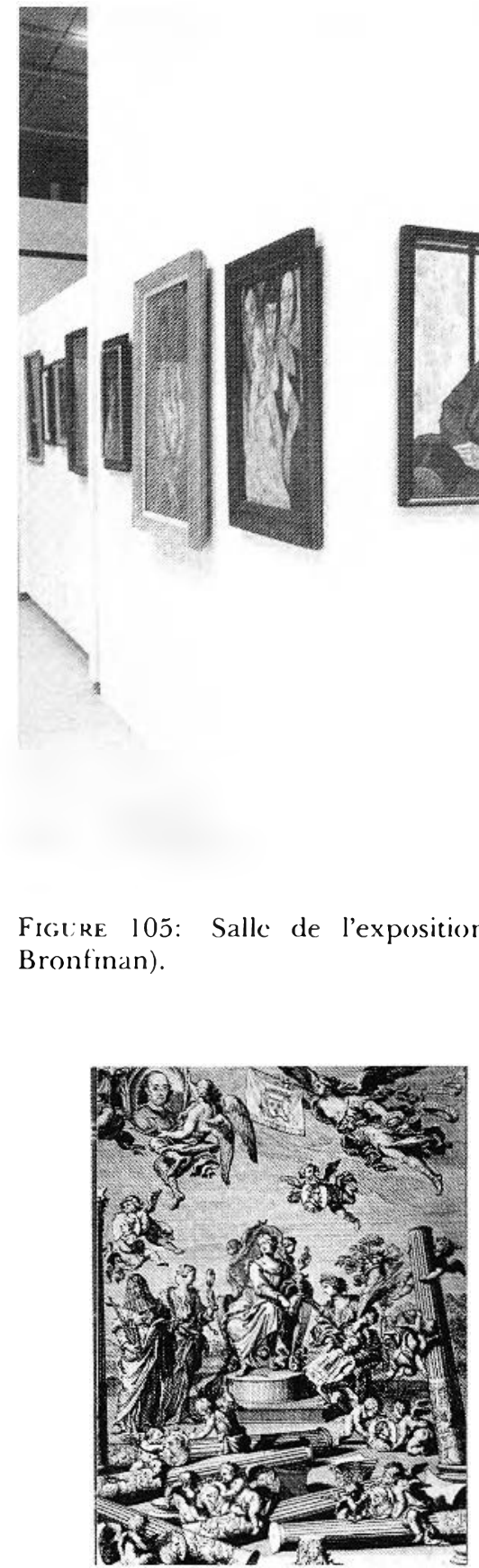

Figure 104. Francesco Trevisani, designcr, frontispiece, Theses iuris publicae disputationi. McGill University I,ibraries, Montreal (Photo: Author).

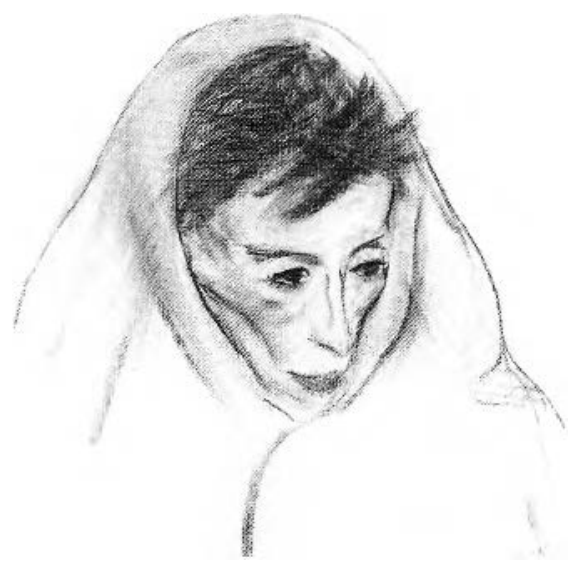

Ficiert 106. Iouis Muhlstock, Paranka, fusain sur papier, 41,9 $\times 31,4 \mathrm{~cm}$. Collection: The Artist (Photo: David Salunarche). 